\title{
The Trade Policies of Brexit Britain: the Influence of and Impacts on the Devolved Nations
}

\author{
David Eiser \\ Fraser of Allander Institute, Department of Economics, University \\ of Strathclyde, Glasgow, UK \\ David.eiser@strath.ac.uk \\ Nicola McEwen \\ Centre on Constitutional Change, School of Social and Political Science, \\ University of Edinburgh, Edinburgh, UK \\ N.McEwen@ed.ac.uk \\ Graeme Roy \\ Fraser of Allander Institute, Department of Economics, University \\ of Strathclyde, Glasgow, UK \\ Graeme.roy@strath.ac.uk
}

\begin{abstract}
This paper examines the extent to which the UK's three devolved governments have sought and achieved influence on the UK Government's evolving post-Brexit international trade policy, distinguishing their influence at key stages of the trade policy cycle (mandate, negotiations and implementation). Despite carrying the legal responsibility to implement those aspects of trade deals that fall within areas of devolved competence, the devolved governments' attempts to secure meaningful influence on the UK's trade agreements have largely been frustrated. This reflects a lack of trust between the devolved and UK governments, weaknesses in the framework for and operation of intergovernmental relations, and a strong desire of the UK government to retain control centrally wherever possible. The resulting tensions have exacerbated devolved governments' concerns over the authority of the devolved institutions post-Brexit.
\end{abstract}




\section{Keywords}

Brexit - trade - devolution - inter-governmental relations - Scotland

\section{Introduction}

Having formally left the European Union (EU) on January 31st, 2020, the United Kingdom (UK) commenced negotiations with its EU counterparts with a view to securing a free trade agreement. These negotiations, which began in March 2020 , are taking place alongside trade negotiations with third countries, with priority given to securing a deal with the United States. These are inter-related processes. The nature and scope of such trade deals with third countries will clearly be influenced by the form of trading relationship that the UK agrees with the EU post-Brexit once the country exits from the 'transition period', at the end of December 2020.

The UK has not negotiated its own trade deal for over 40 years. Prior to Brexit, as a member of the EU's Customs Union, trade deals had been negotiated on its behalf by the EU. But in the decades since the UK last negotiated an independent trade deal, the constitutional landscape of the UK has evolved substantially, notably following the establishment of the devolved legislatures in Scotland, Wales and Northern Ireland in 1999. Whilst the negotiation and ratification of international trade agreements is formally a matter reserved to the UK Government and (to a limited extent) the UK parliament, new trade agreements will have consequences for domestic policy areas that are devolved in Scotland, Wales and Northern Ireland, particularly given the broad terms of modern 'mixed' trade agreements. Further, the devolved governments carry the legal responsibility to implement those aspects of trade deals that fall within areas of devolved competence.

As in many federal and multi-level states, the UK's devolved institutions have sought a role in trade policy. Yet, in the UK, as elsewhere, trade policy lies within the constitutional authority of the UK parliament, and is largely considered a prerogative of the Executive. Despite their legal obligation to implement trade deals, the devolved institutions lack formal veto powers, whose threatened use could bolster demands for a meaningful role in the earlier stages of the trade policy process. Instead, they have relied upon political and pragmatic arguments in favour of greater involvement, from consultation rights to co-decision, especially in the intergovernmental arena. Yet, the UK's system of intergovernmental relations is ad hoc, informal and increasingly characterised by a lack of trust between the devolved governments on the one hand and the UK Government on the other. 
Party political incongruence in the composition of governing administrations - a feature of UK intergovernmental relations (IGR) since 2007 - has made it more difficult to maintain cooperative relationships, especially at ministerial level. Relationships have been further strained by successive constitutional challenges, from the Scottish independence referendum to Brexit. In Scotland, where $62 \%$ of the population voted for the UK to remain in the $\mathrm{EU}$, the government has demanded another independence referendum, arguing that Brexit has resulted in a material change of circumstances from those that surrounded the 2014 independence vote.

The Brexit process has already generated significant tensions and disagreements between the UK government and the devolved governments in Scotland and Wales. In Northern Ireland, which was without a governing executive for much of the first phase of Brexit negotiations leading to the UK's formal exit from the EU, Brexit issues have created particular challenges that have threatened to destabilise the peace process, and generated trade-offs between the east-west and north-south relationships that represent key strands of the Good Friday Agreement. ${ }^{1}$ These tensions have diminished the trust that often makes IGR work.

This article examines the role that the devolved governments have played in the UK's post-Brexit evolving trade policy. In examining the extent to which the devolved governments have sought and achieved influence, the paper distinguishes between three stages of the trade policy process - the negotiating mandate; the negotiations; and policy implementation. It considers, first, negotiations concerning the future trading relationship between the UK and the EU, then the development of trade policy targeted at non-EU ('third') countries. In so doing, it draws upon a blend of sources, including government papers, ministerial statements and letters, political speeches, parliamentary evidence, and meetings with government officials. These are supplemented by informal unrecorded interviews with officials, who have given us insight into otherwise thickly veiled processes of IGR.

Against a backdrop of frustrations at their role in exit negotiations, the article examines the opportunities and constraints facing the devolved governments as they seek fuller involvement in negotiations over the UK's future relationship with the EU and trade deals with third countries. Clearly, these trade negotiations are ongoing, but capturing dynamics as they unfold is critical to identifying the extent of cooperation and strain in IGR, which may in turn shape the territorial governance and territorial future of the UK.

The article begins by providing a comparative context with consideration of the role and influence that can be exercised by sub-state governments in the 
development of trade policy. It then provides an overview of the system of IG R in the UK, drawing attention to its relatively informal and ad hoc nature and the tensions that have already been generated by Brexit. We then examine the role that the UK's devolved governments have sought to play in shaping the terms of the UK's future trading relationships both with the EU and third countries, their aspirations for doing so, and the extent to which these aspirations have been realised. We find that the devolved governments' attempts to have a meaningful role in the development of the UK's negotiating mandates and the trade negotiations themselves have been largely frustrated; at the same time the devolved governments have legitimate concerns that, in seeking to ensure that the implementation of new trade agreements is not impeded, the UK government may seek to constrain devolved competence in some areas. The tensions over trade exacerbate more general concerns on the part of the devolved governments over the authority of the devolved institutions as a result of Brexit.

\section{Trade Policy Making in Federal Political Systems}

In federal political systems, legislative competence and policy making are divided and shared between 'central' institutions acting for the whole state and those representing sub-state territorial jurisdictions. In almost every federal system, the authority to negotiate and conclude trade agreements rests primarily or exclusively with the central or federal parliament. ${ }^{2}$

But trade agreements are not what they used to be. Increasingly, free trade agreements are often deeper, more comprehensive, with a shift from merely 'at the border' tariffs on goods to 'behind the border' regulations and standards. ${ }^{3}$ Leblond and Viju-Miljusevic argued that structural changes in trading relationships since the 1990s have changed the nature of trade agreements. ${ }^{4}$ What they refer to as 'servicification' has seen services, as well as goods, brought to the negotiating table. In addition, the globalisation of production chains has meant that firms' production processes are now dispersed across multiple countries, making trade in production parts a dominant feature of trade agreements. The rise of e-commerce and data flows across borders have also posed new challenges to trade negotiators. These developments, on top of the general reduction on tariffs on goods from successive GATT rounds, have pushed

\footnotetext{
2 Broschek and Goff, Multilevel Politics of Trade, $202 \mathrm{O}$.

3 Lawrence, Regionalism, 1996.

4 Leblond and Viju-Miljusevic, 'EU trade policy', 2019.
} 
negotiators to focus more on reducing regulatory barriers to trade and investment, including labour and environmental standards, health and safety regulations, domestic competition rules, and procurement. ${ }^{5}$ As a consequence, trade negotiations now generate widespread interest beyond goods' manufacturers, with lobbying from NGO s, consumers and citizens. More ambitious and comprehensive trade agreements generally take longer to negotiate, especially where negotiating parties seek policy carve-outs or have to contend with a domestic backlash from those concerned at the impact of agreements on domestic environmental and labour regulations. ${ }^{6}$ Moreover, because these 'third generation' trade agreements affect a much broader range of policies, they have wider implications for the competences of sub-state authorities. This has generated demands from sub-state governments for fuller involvement in trade policy, potentially creating more veto points in the negotiation process.

These demands and pressure points emerge at various stages of the trade policy process. For the purposes of this article, we distinguish four discrete phases. First, in the preparation stage, internal deliberation, consultation and debate informs the development of the negotiating mandate. This establishes the government's overall objectives, its approach to technical issues on standards, regulation and so on, and potentially its approach to process issues internally. The second phase concerns the negotiations themselves, which typically take place over a number of 'rounds', often lasting several years in the case of a comprehensive trade agreement. Third, in the finalisation stage, texts are agreed, and the agreement is signed and ratified. Finally, the agreement is then implemented into domestic law, with processes put in place to allow for monitoring and oversight of the agreement as necessary. The implementation phase is especially important to agreements that span not just tariffs on goods but non-tariff regulatory standards and cooperation. ${ }^{7}$ In federal and multi-level states, the arrangements for oversight may require not just cooperation and coordination between the trading partners, but also mechanisms to ensure sustained implementation of the agreement among all governing administrations.

To understand the role that sub-state governments play in trade policy making, it is helpful to draw a distinction between self-rule and shared rule. Self-rule concerns the decision-making autonomy of each tier of government - the policy fields within which they can make laws, take executive decisions, raise revenues and determine spending independently of central

$5 \quad$ Ibid., pp. 1837-9.

6 Young and Peterson, Parochial Global Europe, 2014; Young, 'Not Your Parents', 2016.

7 Leblond and Viju-Miljusevic, 'EU trade policy', 2019. 
government. No sub-state government has exclusive jurisdiction over trade policy, and few can negotiate their own trade deals. Their competences may, however, be affected by trade agreements, giving them a stake in the trade policy process. Shared rule captures the degree to which sub-state governments can influence those policies, laws and decisions of central or federal governments that affect their competences. Influence may be secured by participating in a territorial second chamber, as in Germany, giving substate governments a formal role in making federal law. More commonly, the intergovernmental arena offers opportunities for sub-state government to shape central government policies and decisions. ${ }^{8}$ The extent to which substate governments can influence those policies and decisions is a yardstick of their level of shared rule. This may range from consultation rights over central government policies to the right to co-determine and, as a corollary, to veto laws, executive decisions, tax and borrowing decisions and international treaties. ${ }^{9}$

The depth of shared rule in a political system provides insight into the influence sub-state governments exercise over trade policy making. In Australia, where the Commonwealth government has exclusive competence for external relations, including international trade, there are few intergovernmental opportunities to be consulted upon, let alone agree, trade mandates or negotiation outcomes. ${ }^{10}$ Formal shared rule is also weak in Canada. The provinces are not represented in the Canadian Senate and the system of IGR is ad hoc and informal. Nonetheless, despite international trade being an exclusive competence of the federal government in Canada, there are opportunities for provincial governments to try to influence negotiation priorities, strategies and outcomes in the intergovernmental arena, including in quarterly meetings of C-Trade, the federal/provincial/territorial committee on trade. ${ }^{11}$ In Germany and Switzerland, regional governments have more formal authority to be consulted and give consent to trade agreements where they affect their policy competences. ${ }^{12}$ Belgium is unusual in the autonomy afforded to each unit of government - federal, regional and community - to agree international treaties in those areas for which each has policy competence. Given the nature of 'third generation' trade agreements, however, that autonomous self-rule in the

\footnotetext{
8 Hueglin and Fenna, Comparative federalism, 2006; Burgess, In Search, 2012.

9 Hooghe, et al., A Postfunctionalist Theory, 2016 pp. 23-29; Ladner, et al., Patterns of Local Autonomy, 2019.

10 Elijah, 'Trade Politics', 2020.

$11 \quad$ Paquin, 'Federalism and the governance', 2013.

12 Broschek et al., 'Parallel Pathways', 2020; Ziegler, 'Federalism', 2020.
} 
Belgian system results in a high degree of shared rule; unless intergovernmental consensus and agreement can be reached between Belgium's administrations, international treaties, including mixed trade agreements negotiated by the EU on behalf of its member states, cannot be endorsed.

The scope of sub-state influence varies with the trade policy cycle. Agreeing a negotiating mandate requires consultation and consensus in Germany and Austria when the subject of negotiations falls within the competence of the Länder. In Switzerland, Cantonal initiatives can be used to request that the federal negotiating team incorporate specific priorities in negotiations. In Canada, the provinces did not enjoy input into the process of agreeing a mandate until the Canada-EU Comprehensive Economic and Trade Agreement (CETA), and then only at the insistence of the European Union. Despite provincial lobbying, the CETA approach does not appear to have set a precedent. ${ }^{13}$

Negotiations themselves usually take place behind closed doors and are led by technocrats representing the central government, but sub-state governments may be connected to these negotiations to a greater or lesser degree. When Australia was negotiating its free trade agreement with the US, states and territories were consulted before and after each negotiating round, with one or more having observer status in each round, albeit not always to their satisfaction. ${ }^{14}$ The Canadian provinces have long sought a greater role in trade negotiations. During the Tokyo Round of the GATT, for example, wealthier and assertive provinces sent representatives to Geneva to try to influence negotiations, with the Quebec government establishing a permanent representation, but the federal government retained its exclusive right to represent Canadian interests at the negotiating table. ${ }^{15}$ In the case of CETA, the provinces were part of the negotiating team - in the room, if not always at the table. They had full access to all draft negotiating documents, participated directly when negotiations affected provincial jurisdiction, but only when invited to do so, and could pass notes to negotiators or request a pause in proceedings. ${ }^{16}$ The degree of provincial involvement in CETA was unprecedented, and although it has raised expectations about future trade negotiations, their more limited involvement in later trade negotiations, including the Trans-Pacific Partnership Agreement (ТРP), exposes the absence of constitutional guarantees.

Trade agreements, once reached between the negotiating partners, are subject to the consent of sub-state governments only to a very limited extent,

\footnotetext{
13 Paquin, 'Federalism and the governance', 2013; Kukucha, 'Neither adapting', 2018.

14 Elijah, 'Trade Pathways', 2020.

15 Freudlsperger, Trade Policy 2020 p. xx.

16 Paquin, 'Federalism and Trade', 2020.
} 
reflecting the broad constitutional authority enjoyed by state-wide governments over trade policy. The German Länder can give or withhold consent within the Bundesrat. In Austria, the Länder can voice a uniform opinion on international treaties affecting their competences, which is intended to bind the federal government, but the latter can override this when a compelling foreign policy case can be made, as it did when faced with Länder opposition to CETA. ${ }^{17}$ The constitutional principle of in foro interno in foro externo, that governs Belgian's external relations, famously gave the regional government of Wallonia the opportunity to use its veto power to threaten to block the ratification of CETA. ${ }^{18}$ In Canada, although the federal government has sole constitutional responsibility for ratifying international treaties, since 2002, any Quebec government must secure the approval of the Quebec National Assembly before it gives its assent.

The opportunity for sub-state governments to influence trade mandates, negotiations and agreements is therefore variable and often limited. But, whereas central governments retain primary authority over the negotiation and agreement of trade deals, sub-state governments carry responsibility to implement those aspects that fall within their spheres of jurisdiction. This is increasingly the case as trade agreements incorporate non-tariff regulations and standards. In Canada, the implementation of trade agreements in areas of provincial jurisdiction lies solely with the provinces; there is no legal device through which the federal government can force compliance.

The role of sub-state governments at different stages of the trade policy process depends significantly on the constitutional requirement for consultation, consent or co-decision making in each phase. Across the devolution settlements in the UK, trade policy is an exclusive competence of the UK parliament, and even that parliament has limited influence over executive action. The devolved governments are therefore reliant on seeking influence through the only shared rule mechanism open to them: IGR. Before examining the extent to which these mechanisms have provided opportunities for the UK's devolved governments to influence trade policy, the next section provides an overview of the nature and dynamics of UK IGR, and the contextual backdrop against which the intergovernmental dimension of trade negotiations is set.

\footnotetext{
17 Broschek et al., 'Parallel Pathways', 2020.
}

18 Bollens et al., 'From Nada to Namur', 2020. 


\section{Brexit and the Evolution of UK Intergovernmental Relations}

When devolution was introduced to Scotland and Wales, it was in response to decades' long campaigns for political autonomy. In Northern Ireland, devolution was reintroduced as part of a package of measures aimed at stabilising peace and reconciliation in this divided community. Across all three cases, then, the devolution process emerged from political dynamics within each territory, and the settlements were geared towards determining the scope of their political autonomy and legislative competence. Devolution was conceived as both an event and a process that happened in Scotland, Wales and Northern Ireland. The absence of devolution in England, by far the largest of the four territories, discouraged the UK government from itself adapting to devolution, or devising a set of processes and structures that could support cooperative working in what had become, by Elazar's broad definition, a federal political system..$^{19}$ As a result, IGR have long been the weak link in the UK's devolution system.

The largely dualist structure of UK devolution also discouraged cooperative decision making. The newly created devolved institutions assumed legislative responsibility for a wide, but variable, range of domestic policy competences. These were mainly areas for which the territorial departments of the UK government had carried administrative responsibility prior to devolution. Consequently, in the early years, there was little need to coordinate policy making with Whitehall departments, while distinctive political dynamics and party competition drove policy debates within each institutional arena. Although ministerial forums to support intergovernmental cooperation were established, it was always envisaged that most communication and cooperation would routinely take place at an informal level, amongst officials. The main ministerial forum, the Joint Ministerial Committee (JMC), was intended to meet annually in plenary format (with the heads of each administration), bi-annually in functional policy formats, and quarterly in a European format.

In the event, only the European JMC met with any regularity, ahead of the meetings of the European Council, partly in recognition of the extent to which many areas of devolved policy were also Europeanised. Plenary meetings were resurrected after 2007, to support relationships between administrations that were now led by opposing political parties. The functional format JMC $s$ gave way to a new 'domestic' format, though it too quickly fell into disuse as a result of the lack of ministerial interest or shared sense of purpose. In an era of

Elazar, 'Exploring Federalism,' 1987. 
heightened constitutional politics, new bilateral forums were created, largely to facilitate the transfer of new competences in taxation and social security. ${ }^{20}$ As these revisions to the devolution settlements saw the devolved institutions assume partial responsibility in policy spheres that are otherwise reserved to the UK parliament, they generated urgent demands for a significant upscaling of the UK's intergovernmental machinery. ${ }^{21}$

It took the Brexit process, however, to generate a radical increase in formal intergovernmental interaction on a multilateral scale. The territorial divergence in Brexit preferences exposed deep fissures in the way in which the UK's relationship with the EU was perceived across its constituent territories. Brexit also posed a direct challenge to the dualist nature of UK devolution. It exposed the interdependence between the reserved competences of the UK parliament, including external relations and trade, and the competences of the devolved institutions. It also opened up the scope for each of the constituent territories to pursue divergent policy paths, once they were freed from the hitherto common obligations created by EU law. In the wake of the Brexit referendum, the JMC met more frequently in its plenary format. New inter-ministerial bodies were also created, including the JMC (EU Negotiations), which from its inception in November 2016 until the UK's departure from the EU in January 2020, met 20 times, despite a six-month hiatus in $2017 .{ }^{22}$

In contrast to cooperative federal systems, which embed joint decision making into their structures, intergovernmental forums in the UK have always been envisaged as providing opportunities for good communication and consideration of the effects of reserved competences on devolved competences, and vice versa. They were explicitly not forums for co-decision or even for policy coordination. ${ }^{23}$ The JMC (EU Negotiations, henceforth JMC EN), however, promised something different. Its terms of reference committed all four administrations to 'work collaboratively' in discussing requirements for the UK's future relationship with the EU and to 'seek to agree a UK approach to, and objectives for, Article 50 negotiations', with oversight of the negotiations to ensure that devolved interests were represented. ${ }^{24}$ This radical departure from previous intergovernmental forums - most of which never had any terms of reference - suggested that the devolved governments would have an

\footnotetext{
$20 \quad$ McEwen, 'Still Better Together', 2017.

21 Silk Commission, 'Empowerment and responsibility', 2014 p. 57; Smith Commission, 'Report of the Smith Commission', 2014.

22 McEwen, 'Negotiating Brexit', 2020.

23 UK Government, 'Memorandum of Understanding', 2013.

24 JMC, Communiqué, 2016.
} 
opportunity to shape the negotiating mandate during exit negotiations, and to continue to influence negotiations as they unfolded to ensure the priorities of the devolved governments were given due consideration. In the event, however, the devolved governments had little influence in shaping the negotiating priorities of the UK government, were nowhere near the rooms in which negotiations took place, and were left frustrated by the lack of communication concerning the negotiations as they unfolded. ${ }^{25}$

The UK-EU Withdrawal Agreement, once reached, required the approval of the UK parliament, as well as that of the European Council, the European Parliament and the Member States. It took a Supreme Court decision, following an appeal initiated by businesswoman Gina Miller, to confirm the necessity of UK parliamentary approval. In the Supreme Court deliberations, the Lord Advocate for Scotland, acting on behalf of the Scottish Government, had argued that the domestic legislation paving the way for the UK's EU exit would also require the consent of the devolved legislatures. This was not about securing veto power; in contrast to federal constitutions, the UK constitution and the sovereignty of the UK parliament prevent the devolved governments from acting as formal veto players. Nonetheless, the constitutional convention that the UK parliament will not legislate in areas of devolved competence, or alter the powers of the devolved institutions, can lend them some influence to shape the devolution dimension of UK legislation.

The Supreme Court ruled that the Sewel convention, as it is commonly known, was beyond its competence; the courts 'cannot give legal rulings on its operation or scope, because those matters are determined within the political world': ${ }^{26}$ However, in the political world of the UK parliament, the EU (Withdrawal) Act 2018, that repealed the legislation that took the UK into the European Community and paved the way for its withdrawal, and the EU (Withdrawal Agreement) Act, that secured parliamentary consent for the UK-EU Withdrawal Agreement, did engage the Sewel convention. In both cases, the Scottish Parliament withheld its consent; in the latter case, it was joined by the other devolved legislatures. In the case of the EU (Withdrawal) legislation, the Sewel process had enabled the Scottish and Welsh governments to secure concessions that significantly changed the extent to which the law would constrain devolved competences. But the withholding of consent could not prevent the enactment of these laws. ${ }^{27}$ One of the consequences of these legal and political disputes was a significant deterioration of the relationship

25 McEwen, 'Negotiating Brexit', 2020.

26 Supreme Court, 'R (Miller) v Secretary of State', 2017: para 146.

27 McEwen, 'Negotiating Brexit', 2020. 
and trust between the administrations. It is against that backdrop that the relationship negotiations, and prospective trade negotiations with third countries, have been taking place.

\section{The Role of the Devolved Governments in Trade Negotiations}

The UK's formal departure from the EU in January 2020 added urgency to negotiations over new trade deals. In contrast to the multi-year processes that trade negotiations often involve, the UK government gave itself just 11 months to secure agreement with the EU on a future trading relationship, having declared its intention not to extend the transition period, even if no formal agreement was reached by December 2020.28 The broad parameters of the future UK-EU economic relationship were expressed in the Political Declaration published alongside the Withdrawal Agreement on 17 October 2020. This envisaged an 'ambitious, broad, deep and flexible partnership across trade and economic cooperation with a comprehensive and balanced Free Trade Agreement at its core' (E). ${ }^{29}$ The negotiations, however, exposed deep divergences over requirements for fair competition and a level playing field, as well as access to fishing waters, data sharing and governance of the relationship. ${ }^{30}$

At the same time, the UK embarked upon trade negotiations with third countries. There are two aspects to these negotiations. First, for those countries with whom the EU has a formal trade agreement in place, the UK sought to 'grandfather' these commitments into domestic legislation - potentially with some modification to the agreements in the process - to be operational by January 2021. Second, the UK is seeking to negotiate trade agreements with countries with whom the EU has no formal trade agreement in place, with particular priority given to a trade deal with the United States, Australia and New Zealand. Somewhere between these two cases, the UK also sought a new trade agreement with Japan, taking the EU-Japan agreement signed in 2019 as a starting point, but with (minor) adjustments in particular areas. In this section, we examine the opportunities and constraints facing the devolved governments in shaping and participating in these trade negotiations.

\section{UK-EU Trade Negotiations}

Within the UK, negotiations on the future relationship with the EU were led by a bespoke unit, Task Force Europe, led by the PM's special adviser, Sir David

\footnotetext{
28 UK Government, The future relationship, 2020: para 9.

29 EU Commission/ UK Government, 'Revised text', 2019: para 17.

3о Kassim, 'UK-EU negotiations', 2020.
} 
Frost. Against a backdrop of deep frustration at the way IGR had been conducted during exit negotiations, the devolved governments sought a fuller 'end-to-end role in the negotiations, starting from agreeing the negotiation mandates through to final agreement. ${ }^{31}$ The Scottish Cabinet Secretary for the Constitution, Europe and External Affairs, Michael Russell, proposed a three room model': in the first room, the UK and devolved governments would put a proposal on a particular issue on the table, with a view to agreeing a position; in the second room, the mandate would be formally agreed; the third room would be where negotiations were conducted by the UK government, 'operating on a mandate that had been agreed by the devolved Administrations.' ${ }^{32}$ For the Scottish Government, the role of the Canadian provinces in CETA negotiations acted as a useful model and reference point for devolved government engagement. For its part, the UK government underlined its commitment to 'working with the devolved administrations to deliver a future relationship with the EU that works for the whole of the UK' ${ }^{33}$

The UK Government on the one hand, and the devolved governments on the other, have markedly distinctive outlooks for Brexit. The Scottish Government, led by the SNP, continues to mourn the UK's departure from the EU, while looking ahead to Scotland re-joining as an independent member state. Nevertheless, it shared with its Welsh counterpart a desire to ensure a UK-EU relationship that remained closely integrated, with membership in, or at least unfettered access to, the EU internal market. Both the Scottish and Welsh Governments also argued that the UK should retain close regulatory alignment with the EU post-Brexit to limit trade and regulatory barriers and to uphold what are perceived as the EU's relatively robust forms of regulatory protections on environmental, social and labour-market issues. ${ }^{34}$ The Scottish Government has introduced a bill to enable ministers to use secondary legislation to ensure that Scots law can 'keep pace' with EU law, with a view to upholding regulatory alignment in areas of devolved competence. By contrast, the current UK administration was committed to leaving the single market and maximising its independent regulatory authority, thus ruling out any commitments to regulatory alignment or oversight by EU institutions. The position of the Northern Ireland Executive was shaped by the power-sharing arrangement between two parties with deeply polarised views on Brexit and the North's

$31 \quad$ Welsh Government, The future UK-EU relationship, 2020 p. 1.

32 Scottish Parliament Culture, Tourism and External Affairs committee, Official Report, 2020: cols 14-15.

33 Gove, Our future relationship, 2020a.

34 Scottish Government, 'Scotland's role', 2018; Welsh Government, The future UK-EU relationship, 2020. 
territorial future. It is further complicated by the Northern Ireland/Ireland protocol, annexed to the Withdrawal Agreement. These divergent positions between administrations contributed to the difficulties faced by the devolved governments in accessing and influencing the negotiations, but constitutional and institutional barriers also played a part.

\section{Agreeing the Mandate}

The UK's negotiating mandate was published on 27 February 2020. ${ }^{35}$ It had been foregrounded by ministerial speeches and a statement by the Prime Minister stressing the importance of a negotiated agreement that gave paramountcy to national sovereignty. As such, the UK vision of an agreement 'cannot therefore include any regulatory alignment, any jurisdiction for the CJEU over the UK's laws, or any supranational control in any area. ${ }^{36}$ The mandate suggested a departure from the approach set out in the Political Declaration, in particular its 'level playing field' commitments, ${ }^{37}$ and is at odds with the EU negotiating mandate on this and other issues, including access to the UK's fishing waters. ${ }^{38}$

The UK's negotiating mandate reiterated the UK Government's view that: 'International relations (including relations with the European Union) remain the responsibility of the UK Government and the UK Parliament. ${ }^{39}$ This reflects the constitutional division of responsibilities in the devolution settlements, as set out in the respective Acts of Parliament that underpin the devolved institutions. Yet, from the outset of devolution, it was recognised that external relations had a devolution dimension. The Memorandum of Understanding and accompanying Concordats that formally underpin relationships between the four administrations gave commitments to involve the devolved administrations 'as directly and fully as possible in decision making on EU matters' when these directly or indirectly touched on devolved matters or the devolved territories. ${ }^{40}$ The mandate noted that 'the UK Government recognises the interests of the devolved administrations in our negotiations with the EU, and their responsibilities for implementation in devolved areas. ${ }^{41}$ Yet the devolved governments had limited input into shaping it.

35 UK Government, The future relationship, 2020.

36 Hansard, UK/EU Relations, 2020.

37 EU Commission/ UK Government, 'Revised text', 2019: XIV.

38 Council of the European Union, 'Annex to Council decision', 2020.

39 UK government, The future relationship, 2020: para. 10.

40 UK government, 'Memorandum of Understanding', 2013 p. 22.

41 UK government, The future relationship, 2020, para. 10. 
Responding to the Prime Minister's statement outlining the UK's negotiation objectives, the Consul General and Brexit Minister for Wales, Jeremy Miles, complained that 'the UK Government has made little effort to take into account our views and concerns in publishing these objectives'. ${ }^{42}$ Addressing a parliamentary committee on 2oth February, the Scottish Government's Constitution, Europe and External Affairs secretary, Michael Russell, noted that the UK mandate - as then set out in the Prime Minister's speech on 3rd February, the Chancellor of the Duchy of Lancaster's statement on 1oth February, and David Frost's lecture on 17th February - had been neither shared with, nor shaped by, the devolved governments:

Devolved Administration ministers have so far been given no chance even to look at it, let alone to influence it. UK ministers cite plenty of meetings taking place, especially among officials, but as yet there has been no sharing of the text of the deal, no role for the devolved Governments in deciding the UK position, and no meaningful ministerial discussion. ${ }^{43}$

Informal interviews with several officials suggest that the devolved governments were given a weekend to comment on the draft text of the mandate before its publication on 27 February. With respect to the draft legal texts published in May, ${ }^{44}$ the devolved governments reported receiving advanced copies just 24 hours prior to their publication, despite 'calling for many weeks' for these to be shared. ${ }^{45}$ Consequently, they had no opportunity to shape the texts, several of which addressed areas that fall within the competence of one or more of the administrations, including fisheries, law enforcement and judicial cooperation, social security coordination, and energy and climate change. None of the texts considered a devolution dimension.

In practice then, despite the UK Government's commitment to 'recognise the interests' of the devolved administrations, the devolved governments themselves were left frustrated by the lack of what they regarded as meaningful engagement around the development of the negotiating mandate, and their consent was never required.

\footnotetext{
42 Miles, Written Statement, 2020a.

43 Scottish Parliament Culture, Tourism and External Affairs Committee, Official Report, 202O, col.4.

44 UK Government, Our approach, 202ob.

45 Miles, 'Written Statement', $2020 b$.
} 


\section{Participation in Negotiations}

While recognising the authority of the UK's negotiating team to conduct the negotiations, the devolved governments sought to ensure these take devolved interests into account. The terms of reference of the JMC (EN) noted its role in providing 'oversight of negotiations with the $\mathrm{EU}$, to ensure, as far as possible, that outcomes agreed by all four governments are secured' 46 Yet, there were limited opportunities for the devolved governments to feed into, or have oversight over, the negotiations as they unfolded.

Whilst policy officials within the devolved governments engaged with their counterparts in Whitehall over future relationship matters, the negotiating strategy, led by Task Force Europe, was tightly controlled by Downing Street, and it is not clear how much input portfolio departments in Whitehall had in shaping it. All three devolved administrations issued a joint call ahead of the second round of negotiations urging 'a meaningful, comprehensive and transparent process for the Devolved Governments... with the opportunity to directly influence the negotiating position: ${ }^{47}$ However, no meetings of the JMC EN were held during the first three months of the negotiations. Instead, regular bilateral telephone discussions took place between the respective Brexit ministers in the devolved governments and the UK Government's Paymaster General, Penny Mordaunt MP, often accompanied by a representative of Task Force Europe. Described as 'summarised readout of the talks after the event', 48 these have updated devolved governments on the progress of negotiations from the UK Government's perspective. But, according to the Scottish Government's Constitutional Secretary, that process was not 'about influencing what is happening still less deciding on crucial issues for which we are responsible. It is merely about hearing what is happening.49 This view was echoed by his Welsh counterpart, who described the UK Government as 'fundamentally uninterested' in the views of the devolved governments..$^{50}$ For its part, the UK Government considers these exchanges as offering 'both before and after each (negotiating) round... an opportunity to contribute.51 They were supplemented by a JMC (EN) meeting on 21 May, the first to be held to date since negotiations began.

\footnotetext{
46 JMC, Communiqué, 2016.

47 Northern Ireland Executive Office, 'Government must engage', 2020.

48 Russell, 'Letter', 2020a.

49 Russell, EU-UK future relationship, 2o2ob.

50 Senedd External Affairs and Additional Legislation Committee, 'Statement', 2020, para. 10.

$5^{1} \quad$ Gove, 'Letter to the Convener', 202ob.
} 


\section{Implementation}

The devolved governments carry the responsibility to implement elements of any trade deal that affect their competences. The devolution settlements give the UK Government the power to ensure that the devolved administrations take action to give effect to international obligations and also do not take actions which would be incompatible with these obligations.

The key Brexit deal in the process of implementation thus far is the Withdrawal Agreement on EU exit and, in particular, the Protocol on Ireland/ Northern Ireland. Under the Protocol, Northern Ireland remains part of the UK customs territory but is required to align with EU rules on customs and regulations.

A Specialised Committee on the Protocol on Ireland/Northern Ireland was established to facilitate the implementation and application of the Protocol. It has no decision-making power itself, but can make recommendations to the EU-UK Joint Committee. The Specialised Committee was tasked with considering: the adequacy of plans for the necessary sanitary and phytosanitary controls, and other regulatory checks on goods moving from the UK to Ireland; which goods are not 'at risk' of onward movement into the EU and so can be exempted from EU customs duties; and the level of agricultural subsidies to producers in Northern Ireland consistent with those producers being able to retain access to the EU market. Despite these matters aligning closely with devolved competence and the broader interests of the Northern Ireland economy, the Specialised Committee is composed formally of EU and UK officials, with representatives from the Northern Ireland Executive invited to be part of the UK delegation on an ad hoc basis.

\section{Trade Agreements with Third Countries}

Like external relations, trade is a reserved competence under the devolution settlements, and thus the power to conclude trade agreements lies within the exclusive authority of the UK Government, acting for the whole of the UK. However, both the Scottish and Welsh Governments have sought to cultivate a role, proposing new arrangements for intergovernmental working. The Welsh Government called for a new Memorandum of Understanding between the four administrations setting out a formal method for engaging with devolved governments on trade issues. This would include 'principles of engagement', including the commitment to 'consult with and seek consent of the Devolved Governments in the development of a UK Trade Policy', supplemented by consultation through each stage of the process, from the 
mandate, to the negotiations, and the subsequent agreement. ${ }^{52}$ The Scottish Government went further, seeking not just engagement and consultation, but formal requirements for the devolved institutions to agree mandates, changes to those mandates during negotiations, and finalised agreements, including formal endorsement and ratification. ${ }^{53}$ It called for a statutory intergovernmental international trade committee, inspired by Canada's (non-statutory) 'C-Trade' Committee but with more force, to consider all aspects of international trade, including agreement on priority regions and sectors, mandates and draft agreements.

From the perspective of the devolved governments, the rationale for their role is principally twofold. First, the sectors implicated by trade agreements are unevenly distributed across the UK nations, and the devolved territories have particular sectoral interests they are keen to protect. For example, Scotland's goods exports are dominated by, on the one hand, petrochemical products; and on the other hand, food and drink (in particular whisky, and fish/seafood). These sectors are relatively much less important for the UK as a whole. Equally however, Scotland does not share the rest of the UK's export strengths in motor vehicles, or medicinal products and pharmaceuticals. Second, and more significantly, the comprehensive nature of FTA s may have a constraining effect on devolved policy making, including in the areas of environment, agriculture, food standards, housing, and public procurement.

The UK Government's broad approach to future trade negotiations was set out in a Command Paper. ${ }^{54}$ It stated the UK Government's intention to work 'collaboratively' with the devolved administrations, although it is envisaged that this collaboration would be carried out 'within the context of the current constitutional make-up of the UK'; in other words, in a context which recognises that trade is a reserved matter under each of the devolution settlements. The UK Government published its own negotiating objectives for a trade deal with the United States in March 2020,55 with negotiations beginning in May 2020. The strategic approach to UK-Japan trade talks was issued in May 2020, ${ }^{56}$ prior to talks beginning in June, with the Strategic Case for negotiations with Australia and New Zealand set out in June 2020. We consider here the extent to which the devolved administrations have been able to shape the mandate and the early negotiations.

$5^{2} \quad$ Welsh Government, Trade Policy, 2018 p. 20.

53 Scottish Government, 'Scotland's role', 2018 p. 52.

54 Department for International Trade, Processes for making, 2019.

55 Department for International Trade, UK-US Free Trade Agreement, $2020 \mathrm{a}$.

56 Department for International Trade, UK-Japan free trade, 2020b. 


\section{Agreeing the Mandate}

UK-US trade negotiations began in May 2020. The UK mandate read in part as a promotional document, setting out analysis to demonstrate how a trade agreement will raise UK economic output and contribute to the UK Government's flagship 'levelling up' agenda. In terms of the detail, the mandate was far less specific than the mandate informing EU discussions.

The Scottish and Welsh Governments had previously expressed concerns that a US trade deal might affect the governance of the devolved health service, could lead to a reduction in existing food safety or animal health and welfare standards, or threaten the devolved governments' ability to pursue domestic public policy objectives, for example, devolved climate change targets or public health initiatives. ${ }^{57}$ However, the UK Government's US mandate made explicit commitments to uphold the UK's high levels of public, animal, and plant health, including food safety, to ensure that decisions on how to run public services are made by governments, including the devolved administrations, and to secure provisions that support and help further the Government's climate change and Net Zero carbon emissions objectives.

Despite concerns, the negotiating mandate therefore seems to align closely with the objectives of the devolved administrations. Informally, officials have informed us that they do not believe this reflects devolved government influence, given the lack of dialogue in the preparation of the mandate. Indeed, the Scottish Government has argued that the negotiating objectives were published 'without any meaningful engagement with the Scottish Government'.58 It also criticised the UK Government for the priority it attached to trade talks with the US, although it did not criticise the substance of the mandate publicly. Instead, the commitments in the mandate appeared to indicate that the starting positions of the UK and devolved governments were not as divergent as is sometimes portrayed. But if the commitments in the mandate are adhered to throughout the negotiations, this would seem to imply that there may be some distance ultimately between the UK Government's rhetoric around the likely economic benefits and the reality.

The UK Government published its Strategic Approach to UK-Japan trade talks in May 2020. Both sides agreed to base the deal on the existing EU-Japan deal, but the UK sought further reductions of tariffs on goods and agriculture and improved market access for services in order to vindicate its Brexit strategy. The UK Government's Strategic Approach argued that Scotland was one

57 see for example Scottish Government, 'Scotland's Role', 2018.

$5^{8}$ Scottish Government, Reckless approach, 2020a. 
of the UK regions with the most scope to benefit from the proposed trade agreement with Japan, on the assumption that the agreement increases existing exports of beverages, power generating equipment and chemicals. However, it provided no explicit role to the devolved governments in shaping the approach, beyond having been invited to submit 'inputs' to the development of the mandate, alongside other stakeholders. In fact the Strategic Approach document is even less detailed than the US mandate - although the commitment to maintain existing sanitary and phytosanitary measures, maintain the devolved governments' decision making responsibilities in relation to devolved public services, and exclude the National Health Service from trade agreements - were copied over largely verbatim from the US mandate. The UK Government's Strategic Approach to trade negotiations with Australia and New Zealand made similar commitments in these areas. Whilst welcoming these broad commitments, the devolved governments questioned why they could not be placed more explicitly in legislation, as discussed below.

\section{Participation in Negotiations}

The UK Government's negotiating framework document committed to 'continue to actively engage with the devolved administrations' regarding any new potential trade deal with the US, including through a new intergovernmental Ministerial Forum for Trade. This new forum met twice in the early part of 2020. No terms of reference for this group have been formally agreed, although this is the norm for the UK's intergovernmental forums.

Informal meetings with officials at the Scottish Government suggest that the UK Government had not shared any meaningful information on the progress of the talks with the US and Japan, whether that be in the form of enhanced access to negotiation documents in areas that might affect devolved competence, or more general updates on progress or sticking points. In the case of the US deal, negotiations are at an early stage, and the lack of engagement is not necessarily indicative of what might happen throughout the process as a whole. However, the UK-Japan trade agreement was finalised by early September 2020, with the devolved governments having had no meaningful engagement at any point.

Thus, despite the UK Government's high level commitments to engagement with the devolved governments to ensure that trade agreements meet the requirements of all parts of the UK, there have been no substantive opportunities for the devolved governments to have oversight of the negotiations with the US or Japan, and, at best, limited opportunity to feed into aspects of those negotiations. 


\section{Implementation}

Comparative examples suggest that implementation is the stage of the trade policy process over which most sub-state governments can have greater influence. Whereas new trade deals have yet to be agreed, by May 2020 the UK had signed agreements with 19 of the countries and trading blocs with whom the EU had an existing agreement, to 'grandfather' these into UK legislation. Discussions were underway with 16 further countries (notably including Canada). ${ }^{59}$ The devolved governments had expressed concern that grandfathered agreements might be modified as they are rolled over, with implementation implications for the devolved administrations. The potential for legislative restrictions to be placed on the devolved governments as part of this grandfathering process has been a significant source of intergovernmental tension.

The UK Trade Bill will provide a legislative device to enable ministers to implement existing trade deals which are rolled over after the end of the UK's transition period with the EU. It also proposes a new Trade Remedies Authority to run the UK's own trade defence policy. Although a Bill of the UK Parliament, the Trade Bill will have implications for the devolved governments, in that they will have responsibility for implementing the grandfathered trade deals - potentially including some modifications to those agreements. As such, the consent of the devolved parliaments was sought, in line with the Sewel Convention.

Whereas the Welsh Government had recommended consent for the Bill, the Senedd Legislation, Justice and Constitution Committee expressed concerns that the interests of Welsh citizens, Welsh businesses, and Welsh democracy were not adequately taken into account in the Bill. It objected particularly to the regulatory powers the Bill gives to UK ministers to alter the legislative competence of the Senedd (Welsh parliament). ${ }^{60}$ For its part, the Scottish Government set aside its objection to an earlier version of the Trade Bill on the basis that the most offensive clauses of it - the restrictions it placed on Scottish Ministers' ability to amend retained EU legislation when exercising the powers of implementation - had been removed. Although it still had concerns about its scope to constrain devolved competence, the risks to businesses in Scotland of disruption to existing trading relationships and access to current and future procurement markets if consent were withheld led it,

59 DIT, Processes, 2020c.

6o Senedd Legislation, Justice and Constitution Committee, 2020, The Welsh Government's Legislative Consent Memorandum on the Trade Bill. 
too, to recommend that consent be granted. ${ }^{61}$ This position was backed by the Scottish Parliament Finance and Constitution Committee, though it reiterated its view that the devolved institutions be involved 'at all stages of the trade negotiation process.' ${ }^{62}$

\section{Conclusions}

One of the principal motivations of Brexit - at least according to some of its proponents - was that the UK could strike trade agreements that were in some way more economically advantageous for Britain than those negotiated by the EU on its behalf. The UK's devolved governments have remained highly sceptical of this argument. Indeed, the UK Government's own analyses suggest that the economic benefits of new trade agreements with third countries are unlikely to compensate for increased trade frictions with the EU market.

The devolved governments have sought to influence the development of the UK's emerging trade agreements, including both the UK's future trade agreement with the EU, and new agreements with third countries including the US, Japan and Australia. Their interests in these agreements is two-fold: first, the sectoral priorities of the devolved economies differ in important respects from those of England; second, the devolved governments carry the legal responsibility to implement those aspects of trade deals that fall within areas of devolved competence. Consequently, they have sought influence at key stages in the development of the UK's trade deals. But they lack constitutional authority to influence these processes, and instead have to rely on a rather weak system of IGR to negotiate influence on an ad hoc basis.

The UK Government has repeatedly stressed its commitment to a consultative approach to trade policy which meets the needs of all parts of the UK. But this commitment is made alongside a firmly expressed view that international trade is a reserved prerogative, repeatedly defending its constitutional authority to act on behalf of the whole of the UK. The devolved governments are effectively asked to trust that the UK Government will bear their interests in mind in the development of negotiating mandates and during the negotiations themselves. But to date there has been no sharing of key mandates or negotiating texts as they are developed, nor scope for the devolved governments to comment on those texts - let alone play a role in any form of co-decision making.

$61 \quad$ Scottish Parliament, 2020, Legislative Consent Memorandum: Trade Bill.

62 Scottish Parliament Finance and Constitution Committee 2020, Report on the Trade Bill 2020. 
The Trade Bill 2020 as introduced makes no requirements for consultation with devolved administrations before draft negotiating mandates and texts of trade agreements are laid before the UK Parliament for final approval, despite the Scottish Government calling for such a requirement to be part of the Bill.

The lack of consultative information sharing is a source of increasing frustration for the devolved governments. Indeed, the Memorandum of Understanding that underpins relations between the UK and devolved governments explicitly recognises that external relations have a devolution dimension. Divergent party-political control of each governing authority adds substantially to the intergovernmental tensions between the UK Government and each devolved government. These tensions heightened during EU exit negotiations and led to a significant breakdown in trust between the governments. That mistrust has been reinforced by the effective exclusion of the devolved governments from future relationship negotiations. In the Scottish case, these tensions are exacerbated by divergent outlooks regarding the constitutional future of Scotland, in the UK or as an independent state.

The tensions about trade are part of a broader picture, the common theme of which is the concern of devolved governments over the authority of the devolved institutions after Brexit. The JMC (EN), set up to give devolved institutions a voice in the exit negotiations, failed to live up to its remit. A ministerial forum for trade has been established outside of the formal JMC framework, but it has no mandate, and offers no guarantees to devolved governments to shape any stage of the trade policy process.

Continued marginalisation of the devolved governments is likely to contribute to a further deterioration of intergovernmental trust and provide a further source of grievance for the devolved governments with respect to their status and authority in the UK. Whether and how this matters may depend on the content and controversies associated with future trade deals, and their implications for business, consumers and lawmakers in the constituent territories of the UK.

\section{Acknowledgements}

Nicola McEwen acknowledges support from a research grant provided by the Economic and Social Research Council (ES/Tooo856/1)

David Eiser and Graeme Roy acknowledge support from a research grant provided by the Economic and Social Research Council (ES/Soo8225/1). 


\section{References}

Bollen, Yelter, et al. 'From Nada to Namur: National Parliaments' Involvement in EU Trade Politics and the Case of Belgium.' In J. Broshek and , P. Goff (Eds.) The Multilevel Politics of Trade. University of Toronto Press, 2020, pp. 256-78.

Broschek, J, P Bußjäger and C Schramek, (2020) 'Parallel Pathways? The Emergence of Multilevel Trade Politics in Austria and Germany', in The Multilevel Politics of Trade Toronto: University of Toronto Press.

Bröschek, J and P Goff, eds, (2020), The Multilevel Politics of Trade Toronto: University of Toronto Press.

Burgess, M. (2012), In Search of the Federal Spirit: New Theoretical and Empirical Perspectives in Comparative Federalism. Oxford: Oxford University Press.

Council of the European Union (2020)Annex to Council decision authorising the opening of negotiations with the United Kingdom of Great Britain and Northern Ireland for a new partnership agreement. https://www.consilium.europa.eu/media/42736/ sto5870-ado1reo3-en2o.pdf.

Department for International Trade (2019) Processes for making free trade agreements after the United Kingdom has left the European Union. Available at: https://assets. publishing.service.gov.uk/government/uploads/system/uploads/attachment_data/ file/782176/command-paper-scrutiny-transparency-27012019.pdf.

Department for International Trade (2020a)UK-US Free Trade Agreement.https://assets. publishing.service.gov.uk/government/uploads/system/uploads/attachment_data/ file/869592/UK_US_FTA_negotiations.pdf.

Department for International Trade (2020b) UK-Japan free trade agreement: the UK's strategic approach. Retrieved from: https://www.gov.uk/government/ publications/uks-approach-to-negotiating-a-free-trade-agreement-with-japan/ uk-japan-free-trade-agreement-the-uks-strategic-approach.

Department for International Trade (2020c) Existing UK trade agreements with non-EU countries. Retrieved from: https://www.gov.uk/guidance/uk-trade-agreementswith-non-eu-countries.

Elazar, D. J. (1987) Exploring Federalism. University of Alabama Press, Alabama.

Elijah, A (2020), 'Trade Politics and the Australian States and Territories', in The Multilevel Politics of Trade Toronto: University of Toronto Press.

EU Commission/ UK Government (2019) Revised text of the Political Declaration setting out the framework for the future relationship between the European Union and the United Kingdom as agreed at negotiators' level on 17 October 2019. Retrieved from: https:// ec.europa.eu/commission/sites/beta-political/files/revised_political_declaration.pdf.

Freudlsperger, C. (2020) Trade Policy in Multilevel Government. Oxford: Ou P.

Gove, M., MP, Chancellor of the Duchy of Lancaster (2020a) Our future relationship with the EU, Oral statement to Parliament, 27 February 2020, available at: https://www. 
gov.uk/government/speeches/our-future-relationship-with-the-eu-chancellor-ofthe-duchy-of-lancasters-statement-to-parliament.

Gove, M., MP, Chancellor of the Duchy of Lancaster (2020b), Letter to the Convener Culture, Tourism, Europe and External Relations Committee, 9 June. https://www. parliament.scot/S5_European/Inquiries/202006o9_UKGovtCDLToConvener.pdf.

Hansard (2020) UK/EU Relations, 3 Feb 2020. Retrieved from: https://www. parliament.uk/business/publications/written-questions-answers-statements/ written-statement/Commons/2020-02-03/HCWS86/.

Hooghe, L., G Marks, A H Schakel, S Chapman, Osterkatz, S Niedzwiecki and S ShairRosenfield, (2016) A Postfunctionalist Theory of Governance. Volume I: Measuring Regional Authority, Oxford: Oxford University Press.

Hueglin, T O and A Fenna (2006) Comparative federalism: a systematic inquiry. Broadview Press.

JMC, 2016. Communiqué, retrieved from: https://www.gov.uk/government/ publications/joint-ministerial-committee-communique-24-october-2016.

Kassim, H (2020) 'UK-EU negotiations: a new optimism?', UK in a Changing Europe blog, 29 June, available at: https://ukandeu.ac.uk/uk-eu-negotiations-a-new-optimism/.

Kukucha, Christopher J. (2018) 'Neither adapting nor innovating: the limited transformation of Canadian foreign trade policy since 1984'. Canadian Foreign Policy Journal, 24:3, 301-315.

Ladner, A., N., Keuffer, H., Baldersheim, N., Hlepas, P., Swianiewicz, K., Steyvers, C., Navarro, (2019), Patterns of Local Autonomy in Europe Palgrave Macmillan.

Lawrence, R. Z. (1996), Regionalism, multilateralism, and deeper integration. Washington, Brookings Institution.

Leblond, P., and Crina Viju-Miljusevic (2019) 'EU trade policy in the twenty first century: change, continuity and challenges', Journal of European Public Policy, 26:12, $1836-1846$.

McEwen, N. (2017) 'Still Better Together? Purpose and Power in Intergovernmental Councils in the UK', Regional \& Federal Studies, vol.27, no.5: 667-69o.

McEwen, N. (2020) 'Negotiating Brexit: power dynamics in British intergovernmental relations'. Regional Studies, forthcoming (available online).

Miles, J., Ms, Consul General and Brexit Minister (2020a), Written Statement: Welsh Government response to the initial UK and EU negotiation mandates, 11 February https://gov.wales/written-statement-welsh-government-response-initial-uk-andeu-negotiation-mandates.

Miles, J., Ms, Consul General and Brexit Minister (2020b), Written Statement: Joint Ministerial Committee (EU Negotiations), https://gov.wales/writtenstatement-joint-ministerial-committee-eu-negotiations-3.

Murphy, M. C., 2018, Europe and Northern Ireland's Future: Negotiating Brexit's Unique Case. Newcastle-upon-Tyne: Agenda Publishing. 
Northern Ireland Executive Office (2020) 'Government must engage with devolved administrations on EU negotiations', joint statement from devolved governments. https://www.executiveoffice-ni.gov.uk/news/government-mustengage-devolved-administrations-eu-negotiations.

Paquin, S (2013) 'Federalism and the governance of international trade negotiations in Canada: Comparing CUSFTA with CETA', International Journal 68(4) 545-552.

Paquin, S, (2020), 'Federalism and Trade Negotiations in Canada: CusfTA, CETA, and TPP Compared. In, J. Bröschek and P. Goff , (eds), The Multilevel Politics of Trade Toronto: University of Toronto Press.

Russell, M, MSP, Cabinet Secretary for Constitution, Europe and External Affairs(2020a), Letter to the Convener Culture, Tourism, Europe and External Relations Committee, 26 May. https://www.parliament.scot/S5_European/Inquiries/20200526_ CabSecCEEAToConvener.pdf.

Russell, M, MSP EU-UK future relationship negotiations. (2020b) Statement by the Cabinet Secretary for Constitution, Europe and External Affairs. Statement to Scottish Parliament, 3June 2020. Retrieved from:https://www.gov.scot/publications/ ministerial-statement-update-eu-uk-future-relationship-negotiations/.

Scottish Government (2018) Scotland's role in the development of future UK trade arrangements: a discussion paper. Scottish Government, Edinburgh.

Scottish Government (2020a) Reckless approach to US trade talks. Press Release. Retrieved from: https://www.gov.scot/news/reckless-approach-to-us-trade-talks/.

Scottish Parliament (2020) Legislative Consent Memorandum: Trade Bill. Scottish Parliament, Edinburgh.

Scottish Parliament Culture, Tourism and External Affairs committee (2020), Official Report, 20 February, http://www.parliament.scot/parliamentarybusiness/report. aspx?r=12530.

Scottish Parliament Finance and Constitution Committee (2020) Report on the Trade Bill LCM. Scottish Parliament Paper 827.

Senedd External Affairs and Additional Legislation Committee (2020) Statement given by Jeremy Miles. Retrieved from: https://record.assembly.wales/Committee/6147.

Senedd Legislation, Justice and Constitution Committee (2020) The Welsh Government's Legislative Consent Memorandum on the Trade Bill, July 2020.

Silk Commission (2014) Empowerment and responsibility: legislative powers to strengthen Wales. Commission on Devolution in Wales, Cardiff.

Smith Commission (2014) Report of the Smith Commission for further devolution of powers to the Scottish Parliament. Smith Commission, Edinburgh.

Supreme Court. (2017). 'R (Miller) v Secretary of State for exiting the European Union', UKSC 5. Retrieved from https://www.supremecourt.uk/cases/docs/uksc-2o16-o196judgment.pdf. 
UK Government (2013). Memorandum of Understanding and supplementary agreements between the United Kingdom government, the Scottish ministers, the Welsh ministers, and the Northern Ireland Executive Committee. Retrieved from https://www.gov. uk/government/uploads/system/uploads/attachment_data/file/316157/MoU_ between_the_UK_and_the_Devolved_Administrations.pdf.

UK Government (2020) The future relationship with the EU: the UK's approach to the negotiations. UK Government, February 2020. https://assets.publishing.service. gov.uk/government/uploads/system/uploads/attachment_data/file/868874/ The_Future_Relationship_with_the_EU.pdf.

UK Government (2020b) Our approach to the Future Relationship with the EU. Retrieved from: https://www.gov.uk/government/publications/our-approachto-the-future-relationship-with-the-eu.

Welsh Government (2018) Trade Policy: the issues for Wales. https:/gov.wales/sites/ default/files/publications/2018-10/trade-policy-the-issues-for-wales_o.pdf.

Welsh Government (2020) The future UK-EU relationship: Negotiating Priorities for Wales. https://gov.wales/sites/default/files/publications/202O-o1/the-future-uk-eurelationship_o.pdf.

Young, A. R. (2016) “Not Your Parents", Trade Politics: The Transatlantic Trade and Investment Partnership Negotiations', Review of International Political Economy, 23:3, 345-78.

Young, A. R., and Peterson, J., (2014) Parochial Global Europe: 21st Century Trade Politics, Oxford University Press, Oxford.

Ziegler, A. R., (2020), 'Federalism in Times of Increased Integration: The Participation of Cantons in Swiss Trade Policy', in The Multilevel Politics of Trade Toronto: University of Toronto Press. 